
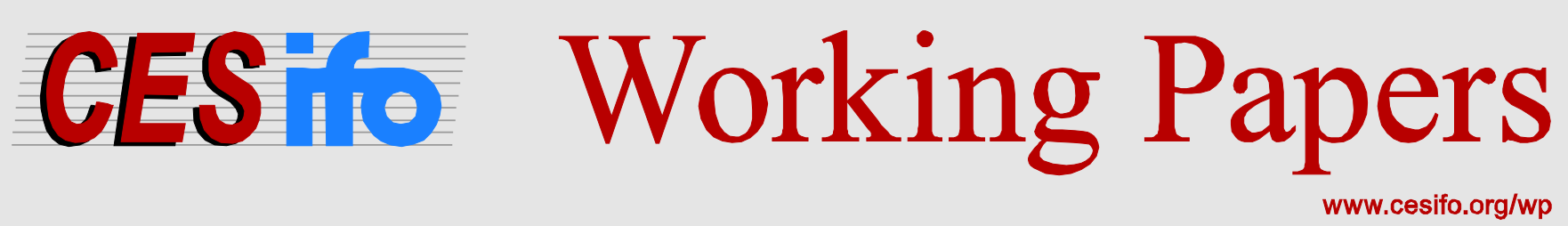

\title{
Nineteenth Century White Physical Activity and Calories: Socioeconomic Status and Diets
}

\author{
Scott Alan Carson
}

\section{CESIFO WORKING PAPER NO. 4886 \\ CATEgORY 2: Public CHOICE \\ JULY 2014}
An electronic version of the paper may be downloaded
- from the SSRN website: Www.SSRN.com
- from the RePEc website: Www.RePEc.org
- from the CESifo website: www.CESifo-group.org/wp




\title{
Nineteenth Century White Physical Activity and Calories: Socioeconomic Status and Diets
}

\begin{abstract}
Using data from late 19th and early 20th century US prisons, this study estimates the basal metabolic rates and calories for Americans of European descent. Throughout the 19th century, white basal metabolic rates (BMRs) and calories declined across their respective distributions, and much of the decrease coincides with economic development. White life expectancy increased at the same time that nutrition decreased, indicating that the most important source of increased life expectancy was not improved nutrition. Physically active farmers had greater BMRs and received more calories per day than workers in other occupations. White diets, nutrition, and calories varied by residence, and whites in the rural Deep South consumed the most calories per day, while Northeastern urban whites consumed the least.
\end{abstract}

JEL-Code: I100, I150, I320, N310.

Keywords: nineteenth century US diets, physical activity, nutrition.

Scott Alan Carson

University of Texas, Permian Basin

4901 East University

USA - Odessa, TX 79762

Carson_S@utpb.edu

I appreciate comments from John Komlos, Marco Sunder, Paul Hodges, Tom Maloney, Martin Conlanvi Konou, Hugh Davis, Larry Wimmer, James Swofford, Gwendolynn Pennywell, Kellye Manning, and Harry Taute. Bryce Harper, Ryan Keifer, Tiffany Grant, Craig Davis, Chinedu Akah, and Shahil Sharma provided excellent research assistance. 
Nineteenth Century White Physical Activity and Calories: Socioeconomic Status and Diets

\section{Introduction}

Nineteenth century increases in wealth and income were associated with increased life expectancy in the Great Britain and the US (Easterlin, 1971; Pope, pp. 276-292; Thomason, 2013, p. 180; Craig 2013, pp. 23-25). However, while material welfare improved, nutrition and biological welfare decreased with industrialization (Komlos, 1987; Carson, 2008, pp. 366-368). Better nutrition, improved public sanitation, and emerging medical intervention are the standard explanations for this disparity; however, the reason for the discrepancy is less clear. Mckeown (1976) finds that nutrition was a principal factor related with $19^{\text {th }}$ century decreasing British mortality, and decreasing infant mortality rates resulted from safer food supplies, especially milk pasteurization. Fogel (1986) extends Mckeown's analysis to the US and finds that improved nutrition was of limited value in explaining increased life expectancies for individuals of European ancestry in the US. ${ }^{1}$ This paper, therefore, uses extant male height, weight, and activity levels from $19^{\text {th }}$ century US prisons to demonstrate that net nutrition declined at the same time that life expectancy increased among individuals of European ancestry.

\footnotetext{
${ }^{1}$ Livi-Bacci (1983) also finds that improved nutrition was not the primary factor associated with declining $19^{\text {th }}$ century mortality. Haines and Anderson (1988) find that public health improvements, better living conditions, and medical intervention were important in declining $19^{\text {th }}$ century mortality. Kim (2002).
} 
A large body of evidence demonstrates that individuals in the $19^{\text {th }}$ century underwent considerable biological adaptation to their physical and economic surroundings, and net nutrition declined with early economic development (Fogel et al. 1978; Steckel, 1979; Komlos, 1987; Fogel, 1994; Carson 2009a; Floud et al. 2011, pp. 15-39). Moreover, in recent decades, significant progress in historical health economics has examined heights and BMIs, which are now widely accepted measures for net nutrition (Fogel et al., 1978; Komlos, 1987; Fogel, 1994). However, while these measures provide important insight into net cumulative and current biological conditions, they provide less information on physical activity and calories available for consumption. At the same time, research from biomedical and health studies have made important headway into the net nutrition required to sustain an individual's height and weight (Mifflin et al., 1990; Weijs et al., 2008). This is particularly suitable in development studies because net calories are an important non-pecuniary measurement to compare biological conditions across populations during economic development.

It is against this backdrop that this study considers three paths of inquiry into $19^{\text {th }}$ century physical activity and net calories for US white working class males. First, throughout the late $19^{\text {th }}$ and early $20^{\text {th }}$ centuries, how did white physical activity and calories vary over time and across their respective distributions, and how did life expectancy change with this nutritional transition? The question is important because increasing life expectancy is typically interpreted to be the result of improved nutrition, better sanitation conditions, and enhanced medical intervention. Throughout the $19^{\text {th }}$ century, BMRs and calories decreased while life expectancy increased, indicating that nutrition was not the most important source of increased US life expectancy. Second, how did white activity levels and calories vary by occupations and socioeconomic status? Physically active white farmers and unskilled workers had higher BMRs 
and received more calories per day than workers in other occupations. Third, how did white BMRs and calories vary by US residence? Rural whites in the Deep South were the most physically active and consumed the most calories per day, while their Northeastern counterparts consumed the least.

\section{Basal Metabolic Rate and Calorie Accounting}

\section{Basal Metabolic Rate and Calorie Accounting}

The basal metabolic rate is the daily amount of calories required by the human body to maintain vital organ function while at rest, awake, and in a warm climate, and BMR is equivalent to about 1400 kilocalories per day or one kilocalorie per minute. Average male BMRs between the ages of 20 and 39 range between 1,350 and 2,000 calories per day, and BMRs are greater at low temperatures and for lean muscle mass. There is a positive relationship between physical activity, fat-free mass, and metabolic rates (Poehlman et al., 1988; Poehlman et al., 1989; Byrne and Wilmore, 2001; Speakman and Selman, 2003; Koshimishu, et al., 2012), and BMRs increase with age through the early 20s and decrease at older ages. As muscle mass declines with age, an individual's ideal BMR decreases; however, factors beyond age also slow BMRs. For example, receiving an insufficient number of calories during one period slows BMRs in future periods because the body comes to anticipate fewer calories in the future and stores current calories when it is deprived of them in the present (Neel, 1962; Prentice, 2005; Prentice et al. 2008; Speakman, 2008).

A second novel approach of basal metabolic rate is its use in estimating calories required to maintain physical dimensions. There is a long history of deriving calories from physical 
measurements, and BMR and calorie equations are used in the biomedical literature to measure the energy required to maintain a given height and weight (Harris and Benedict, 1919; Mifflin et al. 1990, p. 247). ${ }^{2}$ Resting survival calories are about 1.27 times BMRs (Floud, et al. 2011, p. 43); however, because such a diet is only for survival, it does not account for physical activity, such as household production and work.

There are various means to indirectly estimate calories from height, weight, age, and activity levels, and Harrison and Bennidict (1919) were the first to estimate calories from these physical measurements. However, recent equations have been developed to estimate calories required to maintain physical dimensions for populations that more closely resemble $19^{\text {th }}$ century whites. One useful study is Mifflin et al. (1990) that presents equations that are reasonably accurate in estimating calories required in both modern and historical populations (Frankenfield et al., 2003, pp. 1156-1159), and Mifflin et al. equations provide remarkably close estimates for $19^{\text {th }}$ century calories (Floud et al., 2011, p. 314).

Because males and females differ by percent muscle mass, they have different relationships with weight, height, and age.

$$
\begin{gathered}
\text { BMR }_{\text {Male }}=5+10 \times \text { Weight }(\mathrm{kgs})+6.25 \times \text { Height }(\mathrm{cms})-5 \times \text { Age } \\
\text { BMR }_{\text {Female }}=-161+10 \times \text { Weight }(\mathrm{kgs})+6.25 \times \text { Height }(\mathrm{cms})-5 \times \text { Age }
\end{gathered}
$$

These Mifflin et al. equations predict resting BMRs for men and women in healthy, normal to moderately overweight categories, and the normal weight range assumption is important because the majority of $19^{\text {th }}$ century males were in normal weight ranges (Mifflin et al.

\footnotetext{
${ }^{2}$ Harris-Benedict equations for males is $\mathrm{BMR}_{\text {Males }}=66.5+13.75$ weight $(\mathrm{kg})+5.003$ height $(\mathrm{cms})-6.775$ Ageand for women is $\mathrm{BMR}_{\mathrm{Females}}=655.1+9.563$ weight(kg)+1.85height(cms)-4.676Age.
} 
1990, p. 247; Carson, 2009 and 2012). Since calories are estimated from height and weight, some degree of error is expected; nonetheless, Mifflin et al. equations provide reasonable approximations for BMRs. Approximations for average daily calories required to maintain weight and height are then calculated by multiplying estimated BMRs by a reasonable activity ratio.

Because modern activity levels are lower than historic levels, modern activity levels underestimate historical calories. The majority of $19^{\text {th }}$ century white workers were in agricultural occupations (Rosenbloom, 2002, p. 88), and farmers were more physically active than workers in other occupations. To estimate $19^{\text {th }}$ century calories per day, each individual's imputed basal metabolic rate is calculated and sorted by occupation. These imputed occupation values are standardized by dividing each individual's BMR by physically active farmer BMRs. Relative to farmers, the white collar worker imputed BMR value is .9713; average skilled worker imputed values are .9750; average unskilled imputed values are .9900; workers with no occupations are .9885 of imputed farmer values. To calculate calories, these imputed farmer weighted ratios are then multiplied by farmers' extra physical activity ratios of 1.9000 and BMRs. BMRs of workers with no occupation are multiplied by 1.8782; unskilled worker BMRs are multiplied by 1.8810; skilled worker BMRs are multiplied by 1.8525; the white collar BMR is multiplied by $1.8455 .^{3}$

\footnotetext{
${ }^{3}$ Together, BMI, BMR, and energy accounting provide new insights into $19^{\text {th }}$ century biological conditions, and instead of relying on only height and BMIs — two measures that provide no information about the physical activity required to maintain physical dimensions—BMRs provide reliable approximations for physical activity levels, and energy accounting provides the calories necessary to maintain health. Recent evidence also suggests it is difficult to
} 
While Mifflin et al. equations represent an important means to estimate historical calories, they are not above reproach. For example, diets have changed between the late $19^{\text {th }}$ and early $20^{\text {th }}$ centuries (Popkin, 1993), and calories estimated from modern equations may underestimate calories because of the effects of infectious disease (Floud et al., 2011, pp. 289362). However, despite the passage of time, differences in populations, and technological change, Mifflin et al. equations provide reasonable estimates for physical activity and available calories (Frankenfield et al., 2003, p. 1157).

\section{Nineteenth Century US Working Class Whites}

\section{Prison Records}

The data set used in this study is part of a large $19^{\text {th }}$ century prison sample. All state prison repositories were contacted and available records were acquired and entered into a master data set. These prison records include Arizona, California, Colorado, Idaho, Illinois, Kansas, Kentucky, Missouri, New Mexico, Ohio, Oregon, Pennsylvania, Texas, and Washington (Table 1). Most whites in the sample were imprisoned in the Deep South or Border States—Kentucky, Missouri, and Texas. However, whites from the Northeast and Far West are also in the sample.

judge the adequacy of historical diets using modern standards because infectious diseases are significant; it may under -estimate nutrients consumed by 10 percent (Floud et al. 2011, p. 162). 
Table 1, Nineteenth Century US Whites

\begin{tabular}{l|cc}
\hline & $\mathrm{N}$ & $\%$ \\
\hline Arizona & 2,156 & 2.93 \\
Colorado & 3,502 & 4.76 \\
Idaho & 575 & .78 \\
Kentucky & 6,602 & 8.97 \\
Missouri & 7,984 & 10.85 \\
New Mexico & 1,993 & 2.71 \\
Oregon & 1,683 & 2.29 \\
Pennsylvania & 11,214 & 15.24 \\
Philadelphia & 11,410 & 15.51 \\
Tennessee & 10,384 & 14.11 \\
Texas & 16,083 & 21.86 \\
Total & 73,586 & 100.00 \\
\hline
\end{tabular}

Source: Arizona State Library, Archives and Public Records, 1700 W. Washington, Phoenix, AZ 85007; Kentucky Department for Libraries and Archives, 300 Coffee Tree Road, Frankfort, KY 40602; Missouri State Archives, 600 West Main Street, Jefferson City, MO 65102; William F. Winter Archives and History Building, 200 North St., Jackson, MS 39201; New Mexico State Records and Archives, 1205 Camino Carlos Rey, Santa Fe, NM 87507; Tennessee State Library and Archives, $4037^{\text {th }}$ Avenue North, Nashville, TN 37243 and Texas State Library and Archives Commission, 1201 Brazos St., Austin TX 78701.

All historical data have various selection biases, and prison and military records are the most common sources for historical height and weight data. One common shortfall of military samples is a truncation bias imposed by minimum stature requirements (Fogel et al, 1978, p. 85; Sokoloff and Vilaflor, 1982, p. 457, Figure 1; A’Hearn, 2004). Because weight is positively related to height, arbitrarily truncating shorter individuals overestimates BMRs and calories because only taller individuals with greater BMR and calorie requirements remain in military 
samples. Fortunately, prison records do not suffer from this constraint. However, prison records are not above critical examination because they may have selected many of the materially poorest individuals who were drawn from lower socioeconomic groups, that segment of society most vulnerable to economic change (Bogin, 1991, p. 288; Nicholas and Steckel, 1991, p. 944; Komlos and Baten, 2004, p. 199). Moreover, if at the margins of subsistence, demographic and socioeconomic factors were more significant in BMR and calorie variations, prison records may illustrate these effects more clearly because working class diets were more sensitive to economic change. It is also not clear who the prison records represent because law enforcement may have selected many of the materially poorest individuals who resorted to small crimes out of privation. On the other hand, law enforcement may have selected taller individuals involved in assault crimes, because they were larger than other physical assault participants. As a result, law enforcement may have evolved to select more physically fit individuals involved in assault crimes. However, there is little relationship between height and crimes (Carson, 2005, p. 411; Carson, 2007, p. 44). In sum, because most prisoners were unskilled workers incarcerated for theft crimes, prison records likely represent conditions among the working class.

There is also concern over entry requirements, and physical descriptions were recorded by prison enumerators at the time of incarceration as a means of identification, therefore, reflect pre-incarceration conditions. Between 1840 and 1920, prison officials routinely recorded the dates inmates were received, age, complexion, nativity, height, weight, pre-incarceration occupation, and crime. All records with complete age, stature, occupation, height, weight, and nativity were collected. There was care recording inmate stature because accurate measurements had legal implications for identification in the event that inmates escaped and were later recaptured. Arrests and prosecutions across states may have resulted in various selection biases 
that may affect the results of this analysis. However, height and weight within US prisons are consistent with other studies (Steckel, 1979; Margo and Steckel, 1982; Nicholas and Steckel, 1991, pp. 941-943; Komlos, 1992; Komlos and Coclanis, 1997; Bodenhorn, 1999; Floud et al., 2011).

Fortunately, inmate enumerators were thorough when recording inmate complexion and occupations, and enumerators recorded white complexions as light, medium, and dark. Enumerators recorded a wide range of occupations and defined them narrowly, recording over 200 different occupations, which are classified here into four categories: laborers and miners are unskilled workers. Unfortunately, inmate enumerators infrequently distinguished between farm and common laborers. Since common laborers probably encountered less favorable biological conditions during childhood and adolescence, this may overstsate the biological benefits of being a common laborer and underestimate the advantages of being a farm laborer (Carson, 2013). Workers in the agricultural sector are farmers. Light manufacturing, craft workers, and carpenters are skilled workers; merchants and high skilled workers are white-collar workers (Tanner, 1977, p. 346; Ladurie, 1979; Margo and Steckel, 1992; p. 520). Because the purpose of this study is to compare $19^{\text {th }}$ century US white BMRs and calories, females, blacks, and immigrants are excluded from the analysis. 
Table 2, Nineteenth Century White BMIs by Demographics, Residence, and Occupation

\begin{tabular}{|c|c|c|c|c|c|c|c|c|c|}
\hline Ages & $\mathrm{N}$ & $\%$ & BMI & Centimeters & Received & $\mathrm{N}$ & $\%$ & BMI & Centimeters \\
\hline Teens & 10,035 & 13.64 & 21.700 & 169.60 & 1840s & 165 & .22 & 23.43 & 175.37 \\
\hline $20 \mathrm{~s}$ & 36,607 & 49.75 & 22.52 & 171.81 & $1850 \mathrm{~s}$ & 839 & 1.14 & 22.49 & 173.28 \\
\hline $30 s$ & 16,191 & 22.00 & 22.86 & 171.66 & $1860 \mathrm{~s}$ & 1,307 & 1.78 & 22.79 & 172.10 \\
\hline $40 \mathrm{~s}$ & 6,841 & 9.30 & 23.14 & 171.28 & $1870 s$ & 8,748 & 11.89 & 22.35 & 171.11 \\
\hline $50 s$ & 2,841 & 3.86 & 23.24 & 171.04 & 1880s & 10,888 & 14.80 & 22.58 & 171.40 \\
\hline $60 s$ & 896 & 1.22 & 23.04 & 170.63 & $1890 s$ & 14,114 & 19.18 & 22.71 & 171.60 \\
\hline $70 s$ & 175 & .24 & 23.32 & 169.81 & $1900 \mathrm{~s}$ & 17,782 & 24.16 & 22.65 & 170.76 \\
\hline Birth Decade & & & & & $1910 \mathrm{~s}$ & 18,533 & 25.19 & 22.49 & 171.72 \\
\hline $1800 \mathrm{~s}$ & 114 & .15 & 23.10 & 173.23 & 1920s & 1,210 & 1.64 & 22.61 & 171.76 \\
\hline 1810s & 381 & .52 & 23.37 & 173.68 & Occupations & & & & \\
\hline $1820 s$ & 975 & 1.32 & 22.94 & 173.15 & $\begin{array}{l}\text { White- } \\
\text { Collar }\end{array}$ & 7,024 & 9.55 & 22.60 & 171.10 \\
\hline 1830s & 2,295 & 3.12 & 22.97 & 171.66 & Skilled & 32,289 & 22.28 & 22.66 & 170.90 \\
\hline $1840 \mathrm{~s}$ & 5,723 & 7.78 & 22.76 & 171.58 & Farmer & 7,307 & 9.93 & 22.68 & 173.23 \\
\hline $1850 \mathrm{~s}$ & 12,862 & 17.48 & 22.66 & 171.09 & Unskilled & 32,289 & 43.88 & 22.57 & 171.44 \\
\hline $1860 \mathrm{~s}$ & 13,794 & 18.75 & 22.74 & 171.25 & $\begin{array}{l}\text { No } \\
\text { Occupation }\end{array}$ & 10,571 & 14.37 & 22.39 & 170.81 \\
\hline $1870 \mathrm{~s}$ & 14,999 & 20.38 & 22.63 & 171.58 & & & & & \\
\hline $1880 \mathrm{~s}$ & 13,649 & 18.55 & 22.37 & 171.11 & & & & & \\
\hline $1890 \mathrm{~s}$ & 8,144 & 11.07 & 22.13 & 171.60 & & & & & \\
\hline $1900 \mathrm{~s}$ & 650 & .88 & 21.87 & 170.67 & & & & & \\
\hline
\end{tabular}

Sources: See Table 1.

Table 2 presents white inmates’ age, birth decade, occupations, and nativity descriptive statistics. Incarceration was most common among the young (Hirschi and Gottfredson, 1983); 63.4 percent of whites were in their teens and 20s. Whites were primarily from Pennsylvania and Texas, and other prisoners were from the upper South and Far West. Most whites were observed between 1880 and 1910. Reflecting younger ages and poorly developed $19^{\text {th }}$ century institutions to acquire human capital, working class whites in the sample were unskilled or without listed occupations. 


\section{Historical US Nutrition, White BMRs, and Calorie Data}

Historical calorie estimates are available from height, weight, age, and physical activity levels. In addition to Harrison-Benedict and Mifflin et al. calorie equations, there are multiple ways to estimate calories, such as national balance sheets, consumption surveys, health provider books, and poor house, military, and slave plantation records (Rosen, 1999; Floud, et al. 2011, pp. 46-47). National food balance sheets estimate gross food calorie production, while calories from equations provide net calorie estimates, and even modern calorie estimation is problematic because accurately monitoring diets has proven elusive (Weijs et al, 2007, pp. 153-156; Mitka, 2013, pp. 2137-2138). Calories from energy equations also have the advantage of integrating net calories associated with physical size with other personal characteristics, which is not possible with aggregate food balance sheet records.

During the $18^{\text {th }}$ century, British working class males consumed about 2,700 calories per day, while their French counterparts consumed about 2,400 calories per day (Fogel, 1994, p. 372; Fogel and Costa, 1997, p. 52; Floud et al., 2011, p. 56). Cummings (1940) finds that mid-19 ${ }^{\text {th }}$ century US annual white diets averaged 183.9 pounds of meat, 13.2 pounds of lard, 15.1 pounds of butter, 205 pounds of wheat flour, and 29.7 pounds of sweeteners. Cummings also estimates that US diets in 1879 provided 3,741 calories per day, and these calories were sufficient to maintain body weight under moderate to heavy working conditions. Atack and Bateman (1987, p. 210) provide estimates for $19^{\text {th }}$ century diets and conclude that average annual US white diets averaged about 200 pounds of meat, 771 pounds of fluid milk, butter, and cheese, and 13.5 bushels of grain, which provided over 5,000 calories per day (Atack and Bateman, 1987, p. 210). However, Putnam (2000) estimates late $19^{\text {th }}$ century calories to be around 3000 per day. Nineteenth century diets varied regionally, and Shergold (1982, pp. 185-195) finds that 
Northeastern diets were high in grains, breads, and dairy products (Floud et al. 2011, p. 313; US Census, 1975, p. 1175; Comer, 2000, p. 1315). Southern whites consumed more diverse and calorie abundant diets, which included pork, beef, corn and Irish potatoes (Hilliard, 1972).

Using USDA calorie estimates, Putnam (2000) finds that average calorie consumption in 1909 was about 3,500 calories per day, however, decreased to 3,000 calories per day by 1959. In the early 1980s, calories began to increase, which has lasted until the present, and today, instead of minimum nutrition to sustain life, over nutrition is a primary health concern (Flegal et al., 2010; Cawley et al., 2011; Atlas, 2011, p. 103-105; Ogden et al. 2014). Therefore, by combining height, weight, age, and activity levels, basal metabolic rates and calorie accounting provide important insight into understanding historical health and nutrition.

Figure 1, Nineteenth Century White Basal Metabolic Rates and Calories by Age
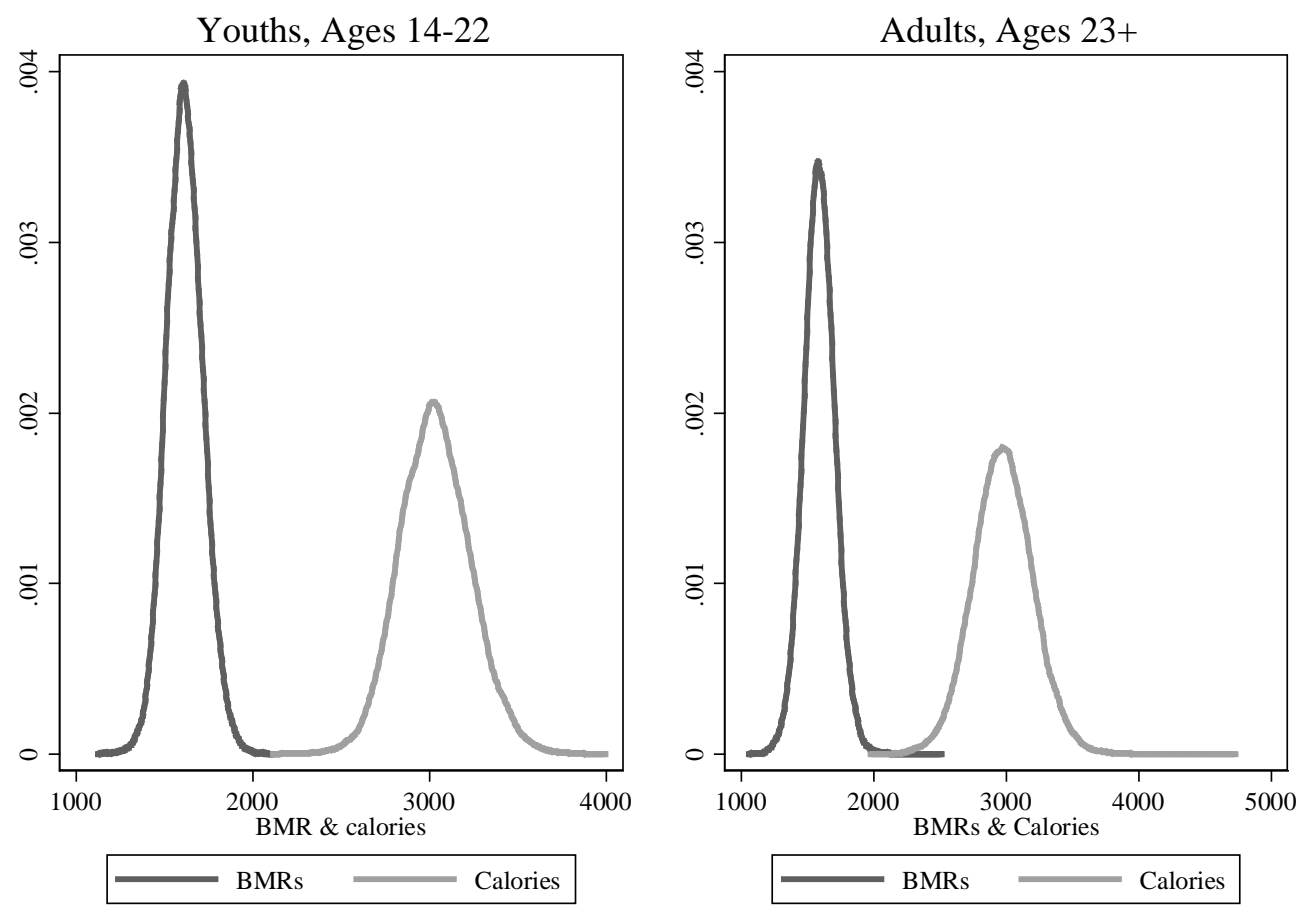

Source: See Table 1. 
How BMRs and calories are distributed provides insight into a population’s physical activity, and Mifflin et al. equations offer a flexible means to assess how BMRs and calories were distributed. Figure 1 presents BMR and calorie kernel density estimates and demonstrates that white BMR and calorie distributions were symmetric; neither too few nor too many calories were available. ${ }^{4}$ Average white youth and adult BMRs were 1,645 and 1,588 calories per day, respectively, and average white youth and adult calories were 3,032 and 2,975 calories per day. ${ }^{5}$ During a period of increased modern obesity, these $19^{\text {th }}$ century diets compare to modern US calories of 3,654 per day (Rosen, 1999, p. 14; Putnam, 2000; Shapouri and Rosen, 2007). Modern Europeans consume 3,394 calories per day, and Asians consume 2,648 calories per day. ${ }^{6}$ Therefore, $19^{\text {th }}$ century US white calories were greater than $18^{\text {th }}$ century French and English calories and compare favorably with calories available in modern developed economies.

V. Demographics, Socioeconomics Status, Geography, and White BMRs and Calories

\section{Quantile Regression}

\footnotetext{
${ }^{4} \mathrm{BMR}$ and calorie distributions are less skewed than income and wealth distributions because the tails of the BMR and calorie distributions are restricted by threshold requirements in the left tail and limited capacity to use energy in the right (Floud et al. 2011, p. 50).

${ }^{5}$ Floud et al. (2011, p. 314) find that average calories were 3,040 calories per day, and average calories from prison records are 2,989, and the difference between these estimated prison calories is one sixth of a cup of oatmeal. ${ }^{5}$ ${ }^{6}$ Asians also have modified BMI thresholds (Must and Evans, 2011, p. 11). The United States Department of Agriculture Economic Research Service defines undernourishment as an available daily per capita food supply of less than 2,100 calories (Rosen, 1999, p. 19).
} 
Quantile regression functions are now constructed to better understand the interaction between socioeconomic and demographic characteristics and the conditional BMR and calorie distributions. Let $y_{\mathrm{i}}$ represent the BMRs and calories of the $\mathrm{i}^{\text {th }}$ individual, and $\mathrm{x}_{\mathrm{i}}$ be the vector of covariates representing birth cohort, socioeconomic status, and demographic characteristics. The conditional quantile functions are

$$
y_{i}=Q_{y}(p \mid x)=\theta x_{i}+\eta S(p), p \in(0,1)
$$

which are the $\mathrm{p}^{\text {th }}$ BMR and calorie quantiles, given $\mathrm{x}_{\mathrm{i}}{ }^{7}$ The interpretation of the coefficient $\theta_{i}$ is the influence of the $\mathrm{i}^{\text {th }}$ covariate on the BMR and calorie distributions at the $\mathrm{p}^{\text {th }}$ quantile. For example, the 22 year old coefficient at the median (.5 quantile) is the number of calories that keeps an average 22 year old inmate's calories on the median relative to the 23-29 age reference category. When estimating BMR and calories, quantile estimation offers advantages over least squares, such as more robust estimation in the face of an unknown truncation point and richer description of covariate effects across BMR and calorie distributions.

We now test how demographic and socioeconomic variables were associated with $19^{\text {th }}$ century white BMRs and calorie allocations. To start, BMRs and daily calories of the $i^{\text {th }}$ individual are assumed to be related with age, socioeconomic status, birth period, and residence.

$$
\begin{gathered}
\text { BMR }_{i}^{p}=\alpha^{p}+\sum_{a=1}^{15} \beta_{a}^{p} \text { Age }_{i} \\
+\sum_{t=1}^{10} \beta_{t}^{p} \text { Decade Received }_{i}+\sum_{l=1}^{3} \beta_{l}^{p} \text { Occupation }_{i} \\
+\sum_{r=1}^{6} \beta_{r}^{p}{\text { Re } \text { sidence }_{i}+\varepsilon_{i}^{p}}^{p}
\end{gathered}
$$

\footnotetext{
${ }^{7}$ The coefficient vector $\theta$ is obtained using techniques presented in Koenker and Bassett (1982) and Hendricks and Koenker (1992).
} 


$$
\begin{gathered}
\text { and } \\
\text { Calories }_{i}^{p}=\alpha^{p}+\sum_{a=1}^{15} \beta_{a}^{p} \text { Age }_{i}+\sum_{t=1}^{10} \beta_{t}^{p} \text { Decade Received }_{i}+\sum_{l=1}^{3} \beta_{l}^{p} \text { Occupation }_{i} \\
+\sum_{r=1}^{6} \beta_{R}^{p}{\text { Re } \text { sidence }_{i}+\varepsilon_{i}^{p}}^{p}
\end{gathered}
$$

Tables 3 and 4's Model 1 presents least squares BMR and calorie estimates for Americans of European descent. Models 2 through 5 illustrate how BMRs and calories were related with demographic, occupation, birth period, and nativity across their respective distributions. Dummy variables are included for youth ages 14 through 22; adult age dummies are included in ten year age intervals for ages 30 through 70 . Decade received dummy variables are in ten year intervals from 1840 through 1920. Occupation dummy variables are for whitecollar, skilled, farmers, and unskilled occupations. Residence dummy variables are included for Arizona, Colorado, Idaho, Kentucky, Missouri, New Mexico, Oregon, Pennsylvania, Philadelphia, and Tennessee. 
Table 3, Nineteenth Century White Basal Metabolic Rates

\begin{tabular}{|c|c|c|c|c|c|c|}
\hline & Model 1 & Model 2 & Model 3 & Model 4 & Model 5 & Model 6 \\
\hline & OLS & $25^{\text {th }}$ & $50^{\text {th }}$ & $75^{\text {th }}$ & $90^{\text {th }}$ & $95^{\text {th }}$ \\
\hline Intercept & $\begin{array}{c}1635.42^{* *} \\
*\end{array}$ & $\begin{array}{c}1563.61 * * \\
*\end{array}$ & $\begin{array}{c}1631.25^{* *} \\
*\end{array}$ & $\begin{array}{c}1702.24^{* *} \\
*\end{array}$ & $\begin{array}{c}1768.17^{* *} \\
*\end{array}$ & $\begin{array}{c}1814.37 * * \\
*\end{array}$ \\
\hline \multicolumn{7}{|l|}{ Ages } \\
\hline 14 & $-167.28 * * *$ & $-181.64 * * *$ & $-163.57 * * *$ & $-178.56 * * *$ & $-161.17 * * *$ & $-121.08 * * *$ \\
\hline 15 & $-117.24 * * *$ & $-112.98 * * *$ & $-112.08 * * *$ & $-121.78 * * *$ & $-104.87 * * *$ & $-89.74 * * *$ \\
\hline 16 & $-70.11 * * *$ & $-59.64 * * *$ & $-69.17 * * *$ & $-79.78 * * *$ & $-82.00 * * *$ & $-90.51 * * *$ \\
\hline 17 & $-38.08 * * *$ & $-30.10 * * *$ & $-32.02 * * *$ & $-40.61 * * *$ & $-51.50 * * *$ & $-62.73^{* * *}$ \\
\hline 18 & $-13.58 * * *$ & $-8.30 * * *$ & $-13.37 * * *$ & $-21.42 * * *$ & $-20.86 * * *$ & $-22.88 * * *$ \\
\hline 19 & 1.58 & $7.45 * * *$ & $2.96 *$ & $-4.85 *$ & $-8.71 * * *$ & $-12.27 * * *$ \\
\hline 20 & $10.39 * * *$ & $12.83 * * *$ & $9.51 * * *$ & $5.08 * *$ & $9.33^{* * *}$ & 3.71 \\
\hline 21 & $13.17 * * *$ & $16.91 * * *$ & $12.13^{* * *}$ & $10.74 * * *$ & $7.83 * *$ & $5.72 * *$ \\
\hline 22 & $11.64^{* * *}$ & $13.66 * * *$ & $13.19 * * *$ & $8.85 * * *$ & 3.64 & 2.78 \\
\hline $23-29$ & Reference & Reference & Reference & Reference & Reference & Reference \\
\hline $30 \mathrm{~s}$ & $-35.23 * * *$ & $-39.28 * * *$ & $-36.78 * * *$ & $-34.23 * * *$ & $-29.08 * * *$ & $-21.13^{* * *}$ \\
\hline $40 \mathrm{~s}$ & $-81.03 * * *$ & $-87.99 * * *$ & $-82.76 * * *$ & $-79.23 * * *$ & $-67.64 * * *$ & $-56.86 * * *$ \\
\hline $50 \mathrm{~s}$ & $-133.59 * * *$ & $-145.57 * * *$ & $-137.13 * * *$ & $-127.12 * * *$ & $-114.72 * * *$ & $-106.80 * * *$ \\
\hline $60 s$ & $-194.33 * * *$ & $-214.02 * * *$ & $-200.72 * * *$ & $-184.90 * * *$ & $-162.98 * * *$ & $-140.06^{* * *}$ \\
\hline $70 \mathrm{~s}$ & $-247.41 * * *$ & $-271.34 * * *$ & $-259.21 * * *$ & $-230.97 * * *$ & $-202.45 * * *$ & $-159.90 * * *$ \\
\hline \multicolumn{7}{|l|}{ Observation } \\
\hline \multicolumn{7}{|l|}{ Period } \\
\hline $1840 s$ & $102.28 * * *$ & $97.58 * * *$ & $107.79 * * *$ & $115.58 * * *$ & $116.31 * * *$ & $113.76^{* * *}$ \\
\hline $1850 \mathrm{~s}$ & $43.14 * * *$ & $40.36 * * *$ & $44.01 * * *$ & $41.33^{* * *}$ & $48.41 * * *$ & $52.21 * * *$ \\
\hline 1860s & $33.81 * * *$ & $30.46 * * *$ & $33.90 * * *$ & $44.03 * * *$ & $30.75 * * *$ & $30.57 * * *$ \\
\hline $1870 \mathrm{~s}$ & $11.43^{* * *}$ & $12.37 * * *$ & $11.95 * * *$ & $9.39 * * *$ & $11.69 * * *$ & $10.16 * *$ \\
\hline $1880 \mathrm{~s}$ & $7.60 * * *$ & $9.69 * * *$ & $9.30 * * *$ & $7.58 * * *$ & $6.93 * * *$ & 4.49 \\
\hline 1890s & $8.93 * * *$ & $10.21 * * *$ & $10.05^{* * *}$ & $8.24 * * *$ & $9.23^{* * *}$ & $5.05 * *$ \\
\hline 1900s & Reference & Reference & Reference & Reference & Reference & Reference \\
\hline 1910s & $-2.19 * *$ & $-2.88 * * *$ & -.260 & -.192 & -.517 & .103 \\
\hline $1920 s$ & $-7.01 * *$ & $-7.09 *$ & -7.49 & -5.22 & .940 & 3.81 \\
\hline \multicolumn{7}{|l|}{ Residence } \\
\hline Arizona & $-24.84 * * *$ & $-24.38 * * *$ & $-25.00 * * *$ & $-21.30 * * *$ & $-21.61 * * *$ & $-20.83 * * *$ \\
\hline Colorado & $-14.88 * * *$ & $-9.82 * * *$ & $-14.43^{* * *}$ & $-19.22 * * *$ & $-16.89 * * *$ & $-17.99 * * *$ \\
\hline Idaho & -.185 & 2.78 & -1.31 & -3.62 & -6.42 & .078 \\
\hline Kentucky & $-36.57 * * *$ & $-35.83 * * *$ & $-34.41 * * *$ & $-36.85 * * *$ & $-33.51 * * *$ & $-36.03 * * *$ \\
\hline Missouri & $-41.84 * * *$ & $-37.94 * * *$ & $-41.46 * * *$ & $-44.56 * * *$ & $-45.38 * * *$ & $-51.80 * * *$ \\
\hline New Mexico & $-6.20 * * *$ & $-5.06 * *$ & -1.60 & $-8.61 * * *$ & -1.08 & 2.83 \\
\hline Oregon & $-10.39 * * *$ & $-8.30 * * *$ & $-12.01 * * *$ & $-10.58 * * *$ & $-9.89 *$ & -7.89 \\
\hline $\begin{array}{l}\text { Pennsylvani } \\
\text { a }\end{array}$ & $-51.84 * * *$ & $-54.43 * * *$ & $-50.95 * * *$ & $-50.57 * * *$ & $-48.86 * * *$ & $-47.97 * * *$ \\
\hline Philadelphia & $-64.74 * * *$ & $-60.61 * * *$ & $-64.40 * * *$ & $-69.44 * * *$ & $-71.94 * * *$ & $-79.64 * * *$ \\
\hline Tennessee & $-11.50 * * *$ & $-8.97 * * *$ & $-10.50 * * *$ & $-11.34 * * *$ & $-12.96 * * *$ & $-13.45^{* * *}$ \\
\hline Texas & Reference & Reference & Reference & Reference & Reference & Reference \\
\hline
\end{tabular}




\begin{tabular}{l|cccccc}
\hline Occupations & & & & & & \\
White-Collar & 1.54 & $-2.43^{*}$ & $-3.65^{*}$ & 1.99 & $8.49^{* * *}$ & $11.13^{* *}$ \\
Skilled & $3.24^{* *}$ & $2.96^{*}$ & $2.57^{*}$ & $3.56^{*}$ & 2.56 & .773 \\
Farmer & $25.36^{* * *}$ & $24.94^{* * *}$ & $23.28^{* * *}$ & $25.56^{* * *}$ & $25.52^{* * *}$ & $23.61^{* * *}$ \\
Unskilled & $10.51^{* * *}$ & $10.82^{* * *}$ & $9.47^{* * *}$ & $11.05^{* * *}$ & $8.57^{* * *}$ & $7.63^{* *}$ \\
No & Reference & Reference & Reference & Reference & Reference & Reference \\
Occupation & & & & & & \\
$\mathrm{N}$ & 73,586 & 73,586 & 73,586 & 73,586 & 73,586 & 73,586 \\
$\mathrm{R}^{2}$ & .1857 & .1227 & .1003 & .0810 & .0628 & .0530 \\
\hline
\end{tabular}

Sources: See Table 1. 
Table 4, Nineteenth Century White Calories

\begin{tabular}{|c|c|c|c|c|c|c|}
\hline & Model 1 & Model 2 & Model 3 & Model 4 & Model 5 & Model 6 \\
\hline & OLS & $25^{\text {th }}$ & $50^{\text {th }}$ & $75^{\text {th }}$ & $90^{\text {th }}$ & $95^{\text {th }}$ \\
\hline Intercept & $\begin{array}{c}3071.21^{* *} \\
*\end{array}$ & $\begin{array}{c}2937.00^{* *} \\
*\end{array}$ & $\begin{array}{c}3063.81^{* *} \\
*\end{array}$ & $\begin{array}{c}3196.47^{* *} \\
*\end{array}$ & $\begin{array}{c}3320.72 * * \\
*\end{array}$ & $\begin{array}{c}3408.39 * * \\
*\end{array}$ \\
\hline \multicolumn{7}{|l|}{ Ages } \\
\hline 14 & $-314.40 * * *$ & $-341.86 * * *$ & $-307.58 * * *$ & $-337.66 * * *$ & $-303.35 * * *$ & $-229.41 * * *$ \\
\hline 15 & $-220.16 * * *$ & $-212.31 * * *$ & $-210.59 * * *$ & $-228.46 * * *$ & $-197.06^{* * *}$ & $-168.22^{* * *}$ \\
\hline 16 & $-131.64 * * *$ & $-111.88 * * *$ & $-129.97 * * *$ & $-149.89 * * *$ & $-154.40 * * *$ & $-170.76^{* * *}$ \\
\hline 17 & $-71.39 * * *$ & $-56.53 * * *$ & $-59.76 * * *$ & $-76.55^{* * *}$ & $-96.66 * * *$ & $-118.22^{* * *}$ \\
\hline 18 & $-25.37 * * *$ & $-15.79 * * *$ & $-25.13^{* * *}$ & $-40.03^{* * *}$ & $-39.40 * * *$ & $-42.90 * * *$ \\
\hline 19 & 2.04 & $14.06 * * *$ & $5.66 *$ & $-8.76 *$ & $-16.55^{* * *}$ & $-22.97 * * *$ \\
\hline 20 & $19.57 * * *$ & $24.36 * * *$ & $17.34^{* * *}$ & $9.29 * *$ & $17.66 * * *$ & 7.16 \\
\hline 21 & $24.82 * * *$ & $31.78 * * *$ & $22.25 * * *$ & $20.40 * * *$ & $14.62 * * *$ & 10.55 \\
\hline 22 & $21.87 * * *$ & $25.78 * * *$ & $24.66^{* * *}$ & $16.95^{* * *}$ & $6.47 * * *$ & 5.25 \\
\hline $23-29$ & Reference & Reference & Reference & Reference & Reference & Reference \\
\hline $30 \mathrm{~s}$ & $-65.98 * * *$ & $-73.57 * * *$ & $-69.01^{* * *}$ & $-64.15^{* * *}$ & $-54.49 * * *$ & $-39.89 * * *$ \\
\hline $40 \mathrm{~s}$ & $-151.76 * * *$ & $-164.88 * * *$ & $-154.78 * * *$ & $-147.92 * * *$ & $-127.02 * * *$ & $-106.70 * * *$ \\
\hline 50s & $-250.15 * * *$ & $-272.85 * * *$ & $-256.59 * * *$ & $-238.50 * * *$ & $-214.68 * * *$ & $-201.52^{* * *}$ \\
\hline 60s & $-363.76 * * *$ & $-403.09 * * *$ & $-375.93 * * *$ & $-347.13 * * *$ & $-306.45 * * *$ & $-262.94 * * *$ \\
\hline $70 \mathrm{~s}$ & $-463.08 * * *$ & $-501.71 * * *$ & $-480.21^{* * *}$ & $-430.43 * * *$ & $-380.22 * * *$ & $-303.25 * * *$ \\
\hline \multicolumn{7}{|l|}{ Observation } \\
\hline \multicolumn{7}{|l|}{ Period } \\
\hline 1840s & $192.16^{* * *}$ & $182.92 * * *$ & $202.53 * * *$ & $217.68 * * *$ & $218.12 * * *$ & $213.04 * * *$ \\
\hline 1850s & $80.98 * * *$ & $75.00 * * *$ & 82.98*** & $78.25^{* * *}$ & $90.78 * * *$ & $98.12 * * *$ \\
\hline 1860s & $63.46 * * *$ & $57.20 * * *$ & $63.54 * * *$ & $82.56 * * *$ & $57.87 * * *$ & $57.39 * *$ \\
\hline 1870s & $21.45 * * *$ & $23.23 * * *$ & 22.70 *** & $17.90 * * *$ & $22.20 * * *$ & $18.37 * * *$ \\
\hline $1880 \mathrm{~s}$ & $14.36^{* * *}$ & $18.10^{* * *}$ & $17.48^{* * *}$ & $14.33^{* * *}$ & $13.41 * * *$ & 8.32 \\
\hline 1890s & $16.78 * * *$ & $19.17 * * *$ & $19.05^{* * * *}$ & $15.45^{* * *}$ & $17.46 * * *$ & 9.70 \\
\hline $1900 \mathrm{~s}$ & Reference & Reference & Reference & Reference & Reference & Reference \\
\hline 1910s & $-4.28 *$ & $-5.61 * * *$ & -.660 & -.725 & -.958 & -.454 \\
\hline 1920s & $-13.48 * * *$ & $-13.07 * * *$ & -13.45 & $-10.13^{* * *}$ & 1.10 & 7.58 \\
\hline \multicolumn{7}{|l|}{ Residence } \\
\hline Arizona & $-46.56^{* * *}$ & $-46.66 * * *$ & $-46.26 * * *$ & $-39.85 * * *$ & $-40.63 * * *$ & $-38.78 * * *$ \\
\hline Colorado & $-27.89 * * *$ & $-18.69 * * *$ & $-26.74 * * *$ & $-35.51 * * *$ & $-32.01 * * *$ & $-33.48 * * *$ \\
\hline Idaho & -.382 & 5.15 & -3.17 & -6.06 & -12.09 & .583 \\
\hline Kentucky & $-68.56^{* * *}$ & $-67.13^{* * *}$ & $-64.76^{* * *}$ & $-69.46 * * *$ & $-62.67 * * *$ & $-67.89 * * *$ \\
\hline Missouri & $-78.38 * * *$ & $-71.07 * * *$ & $-77.49 * * *$ & $-83.32 * * *$ & $-85.29 * * *$ & $-96.52 * * *$ \\
\hline New Mexico & $-11.44 * *$ & $-10.98 * * *$ & -3.56 & $-16.27 * * *$ & -2.05 & 4.79 \\
\hline Oregon & $-19.61 * * *$ & $-15.85 * * *$ & $-23.25 * * *$ & $-19.64 * * *$ & $-18.68 * * *$ & -15.24 \\
\hline $\begin{array}{l}\text { Pennsylvani } \\
\text { a }\end{array}$ & $-97.16 * * *$ & $-102.12 * * *$ & $-95.60 * * *$ & $-94.11 * * *$ & $-91.92 * * *$ & $-90.73 * * *$ \\
\hline Philadelphia & $-121.29 * * *$ & $-114.10 * * *$ & -120.81 & $-130.10 * * *$ & $-134.87 * * *$ & $-149.49 * * *$ \\
\hline Tennessee & $-21.51^{* * *}$ & $-17.24 * * *$ & $-20.14^{* * *}$ & $-21.04 * * *$ & $-24.25^{* * *}$ & $-26.10^{* * *}$ \\
\hline Texas & Reference & Reference & Reference & Reference & Reference & Reference \\
\hline
\end{tabular}




\begin{tabular}{l|cccccc}
\hline Occupations & & & & & & \\
White-Collar & $-48.53^{* * *}$ & $-53.90^{* * *}$ & $-57.93^{* * *}$ & $-49.35^{* * *}$ & $-39.89^{* * *}$ & $-36.65^{* * *}$ \\
Skilled & $-34.39^{* * *}$ & $-33.39^{* * *}$ & $-35.94^{* * *}$ & $-35.54 * * *$ & $-39.23^{* * *}$ & $-44.31^{* * *}$ \\
Farmer & $83.14^{* * *}$ & $79.68^{* * *}$ & $78.71^{* * *}$ & $84.82^{* * *}$ & $86.57^{* * *}$ & $83.85^{* * *}$ \\
Unskilled & $24.58^{* * *}$ & $24.61^{* * *}$ & $22.31^{* * *}$ & $26.04^{* * *}$ & $21.30^{* * *}$ & $19.17^{* * *}$ \\
No & Reference & Reference & Reference & Reference & Reference & Reference \\
Occupation & & & & & & \\
$\mathrm{N}$ & 73,586 & 73,586 & 73,586 & 73,586 & 73,586 & 73,586 \\
$\mathrm{R}^{2}$ & .2158 & .1390 & .1188 & .0997 & .0807 & .0693 \\
\hline
\end{tabular}

Source: See Table 1. 
Three general patterns emerge when comparing white BMRs and calories. First, throughout the $19^{\text {th }}$ century, BMRs and calories declined across their distributions, and much of the decline coincided with US industrialization and was, therefore, structural (Comer, 2000, p. 1314; Carson, 2008, pp. 360-369). Most of the $19^{\text {th }}$ century US labor force was in physically active agricultural occupations; however, between 1870 and 1920, the agricultural sector declined as a share of the US labor force by 38 percent (Rosenbloom, 2000, p. 88; Federico, 2013), and industrialization moved physically active farmers into factories where their physical activity decreased. Low and declining BMRs indicate that changing $19^{\text {th }}$ century labor market conditions coupled with improved agricultural technology placed previously active workers into physically less active occupations (Comer, 2000, p. 1312). Moreover, the separation of workers from close proximity to agricultural diets rich in animal proteins and complex carbohydrates was associated with the beginning of the transition from diets high in proteins and complex carbohydrates to diets high in saturated fats and simple sugars (Popkin, 1993, pp. 145-148; Comer, 2000, p. 1314). This prolonged and widespread decrease in white nutrition is also important because average nutrition declined by five percent, while life expectancy increased by over 30 percent, (Figure 2) and three factors are associated with increased life expectancy: better nutrition, improved sanitation conditions, and enhanced medical intervention (Mckeown, 1976; Fogel, 1986, Preston, 1975; Kim, 2000). However, decreasing late $19^{\text {th }}$ and early $20^{\text {th }}$ century US white calories as life expectancy increased indicates that increased life expectancy was not primarily due to better nutrition (Fogel, 1986; Haines and Anderson, 1988; Fogel, 1994; Oeppen and Vaupel, 2002, p. 1029). Consequently, white physical activity and net nutrition declined 
throughout the late $19^{\text {th }}$ and early $20^{\text {th }}$ centuries, and increasing life expectancies was due to better sanitation and medical intervention (Mckeown; 1976; Fogel, 1997).

Figure 2, Nineteenth Century White Basal Metabolic Rates and Calories over Time and across

\section{Distributions}
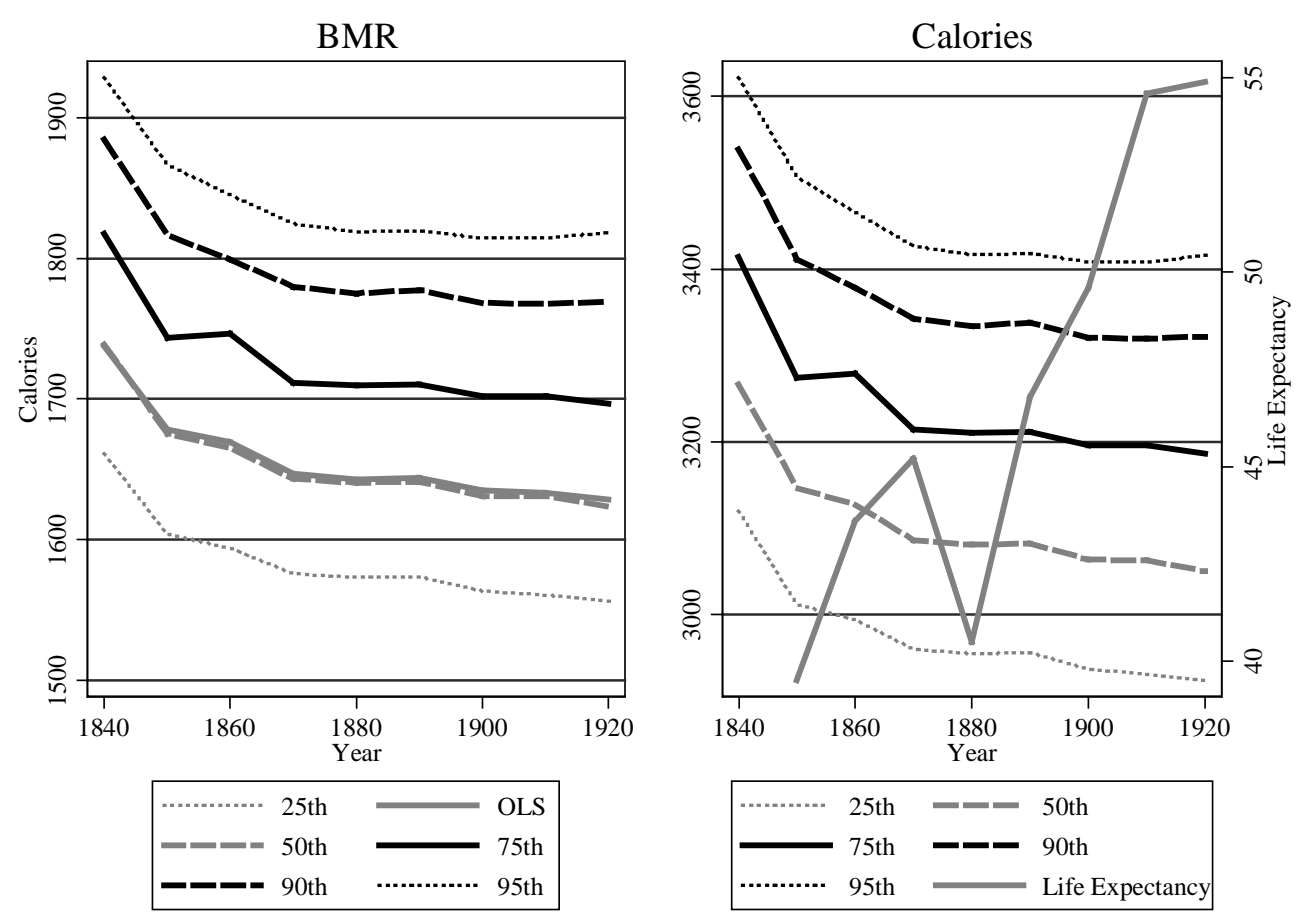

Source: Tables 3 and 4 . 
Figure 3, Nineteenth Century White Basal Metabolic Rate and Calorie Marginal Effects by Occupations across Quantiles
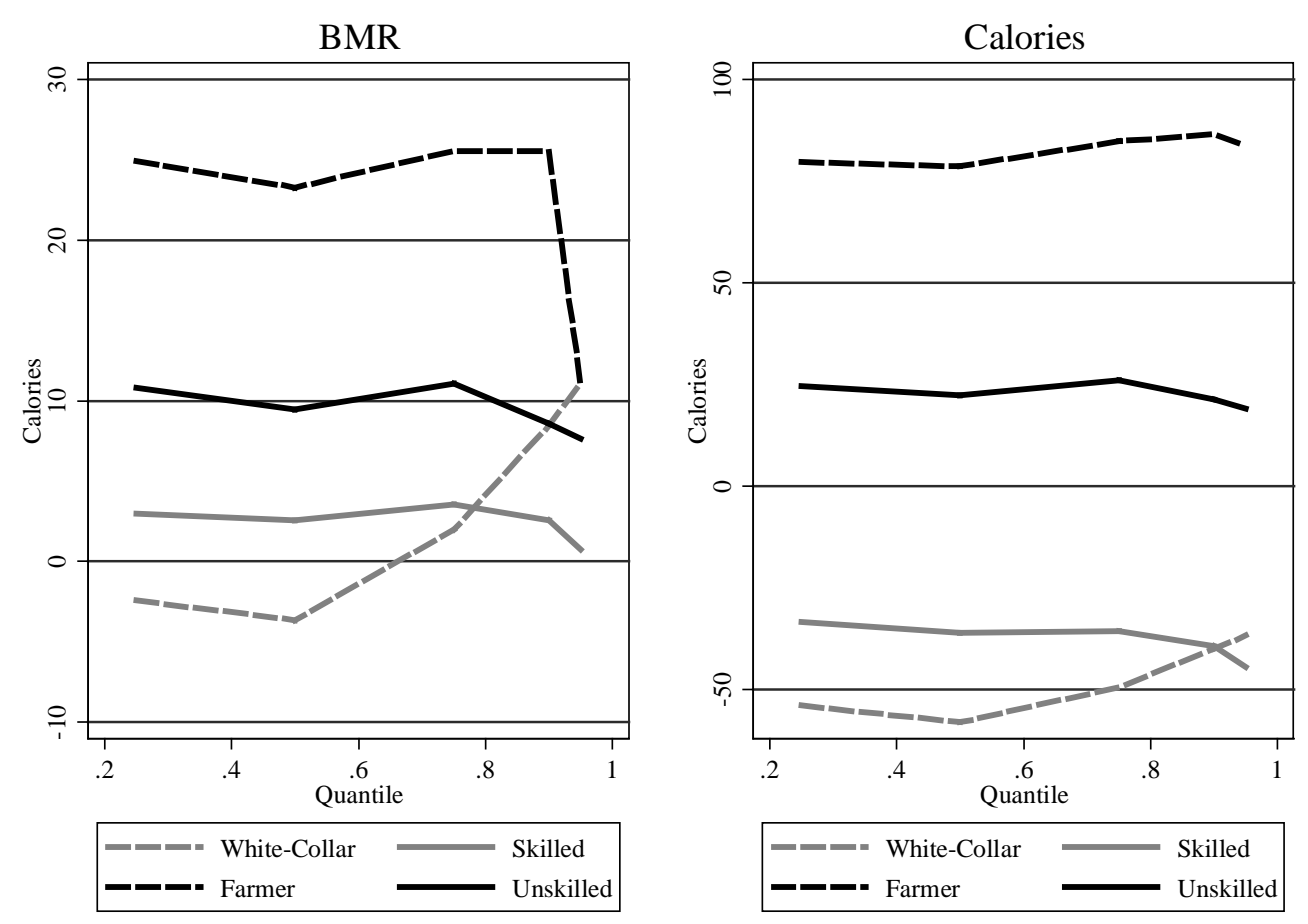

Source: Tables 3 and 4.

Second, BMRs and calories are related to occupations and socioeconomic status, and physically active farmers consistently had greater BMRs, were more physically active, and received greater calorie allocations per day than workers in other occupations (Figure 3). BMRs are a reasonable indicator of physical activity and high $\mathrm{BMI}^{8}$ combined with a high BMR indicates a person is active and in better physical condition. Individuals with high BMIs and low BMRs are physically less active and in poorer physical health (Strauss and Thomas, 1998, p.

${ }^{8} \mathrm{BMI}=\frac{\text { Weight }(\mathrm{kg})}{(\text { Height }(\mathrm{mt}))^{2}}$. 
774; Poston et al. 1999; Stevens et al. 2002; Wardlaw, Hampl, and DiSilvestro, 2004; Must and Evans, 2011, p. 25). Part of greater farmer calories was because they were more physically active than workers in other occupations. Alternatively, white collar and skilled workers were removed from rural diets, were physically less active than farmers and unskilled workers (Figure 3), and received fewer calories per day. In sum, farmers and unskilled workers were taller, had heavier BMIs, greater BMRs, and consumed more calories per day than workers in other occupations and were in better physical condition than workers in other occupations (Poston et al. 1999; Stevens et al. 2002; Wardlaw, Hample, and Divilvestro, 2004; Must and Evans, 2011).

Third, BMRs and calories varied by residence and across their distributions, and rural white Texans had both greater BMRs and consumed more calories per day than workers elsewhere within the US (Hilliard, 1972, p. 62-69; Fogel, 1994, 136; Bodenhorn, 1999, p. 988). When Texas was admitted into the Union in 1846, it was the only state that retained its right to distribute its public domain independently from federal influence, and to attract and maintain its population, early Texas land policies were established to liberally distribute land into the private sector. By 1870, easy land policies led to a large-scale cattle industry (Cochrane, 1977, pp. 8889), and animal proteins and fats are more calorie-dense then plant-based crops (Hilliard, 1972, pp. 63-64). Southern whites also had access to more diverse and abundant diets, which included potatoes, corn, beef, and pork (Hilliard, 1972, pp. 62-63; Comer, 2000, p. 1311). Alternatively, BMRs and calories where lower in the Upper South, which was agriculturally less productive than the Deep South. Farther north in industrializing Philadelphia and Pennsylvania, $19^{\text {th }}$ century urban diets included early processed foods from the developing canning industry, fewer animal proteins from diets where staples were starches and breads, and white physical activity and calories were lowest in the urban industrialized Northeast (Hilliard, 1972; Cochrane, 1977, p. 72; 
Shergold, 1982, pp. 185-189; Popkin, 1993, pp. 145-146; Comer, 2000, p. 1311). Subsequently, $19^{\text {th }}$ century US diets of individuals of European descent varied by residence, and across their daily BMR and calorie distributions, individuals in the Deep South had greater BMRs, and access to rural agricultural diets, which required greater physical activity but were compensated with better net nutrition.

\section{Conclusion}

This study uses two less frequently considered biological measurements - the basal metabolic rate and calorie accounting — to arrive at new findings for a generation's old question on the nature of $19^{\text {th }}$ century biological conditions. White BMRs and calories declined throughout the $19^{\text {th }}$ century and across their distributions, and declining calories occurred at the same time that life expectancy increased, which indicates that better nutrition was not the primary source of increasing $19^{\text {th }}$ century white life expectancy. BMR and calorie accounting also offers insight into health by occupations and socioeconomic status. Farmers and unskilled workers were more physically active, received more calories per day, and were in better health than skilled and white-collar workers. Industrialization required less work effort than for workers in agricultural occupations, and physical activity and calories declined as workers moved from fields into factories. The share of workers in physically active agricultural occupations declined throughout the late $19^{\text {th }}$ and early $20^{\text {th }}$ centuries, labor saving devices, such as the gas powered tractor, made farming less physically demanding. Basal metabolic rates and calorie accounting also offer insights into regional diets and nutrition. The South had higher

disease rates and suffered from the social malignancy of slavery. However, during the early $19^{\text {th }}$ century, the rural South produced a net agricultural surplus, and BMRs and calories were the highest in rural Texas and lowest in urban Philadelphia, indicating that although the South had 
higher disease rates, it produced a calorie surplus relative to work effort performed. Therefore, as $17^{\text {th }}$ and $18^{\text {th }}$ century European workers toiled to produce a sufficient number of calories to maintain health, their progenitors in the US had greater net nutrition; however, this nutritional advantage declined as industrialization and urbanization separated farm consumption from farm production. 


\section{References}

A’Hearn, B., 2004. A Restricted Maximum Likelihood Estimator for Truncated Height Samples. Economics and Human Biology 2, 5-20.

Atack, J., Bateman, F., 1987. To Their Own Soil: Agriculture in the Antebellum North. Iowa State University Press, Ames, Iowa.

Atlas, Scott. 2011. In Excellent Health: Setting the Record Straight on America's Health Care. Hoover Institution Press.

Bodenhorn, H., 1999. A Troublesome Caste: Height and Nutrition of Antebellum Virginia’s Rural Free Blacks. Journal of Economic History 59, 972-996.

Bogin, Barry, "Measurement of Growth Variability and Environmental Quality in Guatemalan Children,” Annals of Human Biology, 18(4), 1991, pp. 285-294.

Bryne, Heide and Jack Wilmore (2001). “The Relationship of Mode and Intensity of Training on Resting Metabolic Rate in Women.” International Journal of Sport Nutrition and Metabolism, 11, 1-14.

Carson, Scott Alan. (2005) “The Biological Standard of Living in 19th-Century Mexico and in the American West,” Economics and Human Biology, Volume 3(3), pp. 405-419.

Carson, Scott Alan. (2007) “Mexican Body Mass Index Values in the $19^{\text {th }}$ Century American West,” Economics and Human Biology, Volume, 5(1), pp. 37-47.

Carson, Scott Alan. (2008) “The Effect of Geography and Vitamin D on AfricanAmerican Stature in the $19^{\text {th }}$ Century: Evidence from Prison Records,” Journal of Economic History, 68(3), pp. 812-830.

Carson SA (2009a) “Geography, insolation, and vitamin D in $19^{\text {th }}$ century US 
African-American and white statures.” Explorations in Economic History 46: $149-159$

Carson SA (2009b) "Racial differences in body-mass indices of men imprisoned in $19^{\text {th }}$ Century Texas.” Economics and Human Biology 7: 121-127

Carson. Scott Alan (2012) “The Body Mass Index of Blacks and Whites in the United States during the $19^{\text {th }}$ Century,” Journal of Interdisciplinary History, 371-391.

Carson, Scott Alan. (2013). "Biological Conditions and Economic Development: Westward Expansion and Health in Late $19^{\text {th }}$ and Early $20^{\text {th }}$ Century Montana.” Journal of Historical Society,13(1), pp. 51-68.

Cawley, John. 2011 “The Economics of Obesity.” In: The Oxford Handbook of The Social Science of Obesity. John Cawley (ed.) Oxford: Oxford University Press, 120-137.

Cochrane, Willard. The Development of American Agriculture. Minneapolis: University of Minnesota Press, 1979.

Comer, James (2000) “North America from 1492 to the Present.” In Kenneth Kiple and Kriemheld Ornelas (Eds.). The Cambridge Word History of Food. Cambridge: Cambridge University Press. pp. 1304-1323.

Costa, Dora and Richard Steckel (1997). "Long-Term Trends in Health, Welfare, and Economic Growth in the United States.” In: Richard H. Steckel and Roderick Floud, (Eds.). Health and Welfare during Industrialization. University of Chicago Press: Chicago. pp. 47-90.

Craig, Lee (2013). “Measuring Economic Growth and the Standard of Living.” In Robert Whaples and Randall Parker (Eds.) Routledge Handbook of Modern Economic History. Routledge: New York. pp. 23-32.

Crimmens, E. and G. A. Condran. "Mortality Variation in U.S. Cities in 1900: A Two Level 
Explanation by Cause of Death and Underlying Factors." Social Science History. 7, no. 1 (1983): 31-59.

Cummings, Richard O. 1940. The American and his Food. Chicago: University of Chicago Press.

Easterlin, Richard (1971). “Regional Income Trends, 1840-1950,” In: Robert Fogel and Stanley Engerman. (Eds.). The Reinterpretation of American Economic History. Harper Row: New York. pp. 38-53.

Federico, Giovanni. (2013). “The Economic History of Agriculture.” In Robert Whaples and Randall Parker, (Eds.). Routledge Handbook of Modern Economic History. Routledge Press: New York, pp. 156-166.

Flegal, K., Carroll, M., and Ogden, C, (2010) 'Prevalence and trends in obesity among US adults, 1999-2008', Journal of the American Medical Society, 303: 235-241.

Floud, Roderick, Robert W. Fogel, Bernard Harris, and Sok Chul Hong. (2011). The Changing Body: Health, Nutrition, and Human Development in the Western World since 1700. Cambridge: Cambridge University Press.

Fogel, Robert W. and Stanley Engerman, Time on the Cross. New York: W. W. Norton, 1974.

Fogel, Robert, Stanley Engerman, James Trussell, Roderick Floud, Clayne Pope, and Larry Wimmer, 1978, “Economics of Mortality in North America, 1650-1910: A Description of a Research Project,” Historical Methods, 11(2), pp. 75-108.

Fogel, Robert W. "Nutrition and the Decline in Mortality since 1700: Some Preliminary Findings." In Long-term Factors in American Economic Growth. edited by Stanley Engerman and Robert Gallman. Chicago, IL: University of Chicago Press, 1986. 439- 
527.

Fogel, R.W., 1994. Economic Growth, Population Theory and Physiology: The Bearing of Long-Term Processes on the Making of Economic Policy. American Economic Review 84, 369-395.

Fogel, Robert W. (1997). "New Findings on Secular Trends in Nutrition and Mortality: Some Implications for Population Theory." In Handbook of Population and Family Economics, Volume 1B. edited by Mark Rozenwieg and Oded Stark. Amsterdam; ElSevier,. 443469.

Fogel, R.W., 1994. Economic Growth, Population Theory and Physiology: The Bearing of Long-Term Processes on the Making of Economic Policy. American Economic Review 84, 369-395.

Fogel, Robert W., and Dora Costa. (1997). "The Theory of Technopysio Evolution, With Some Implications for Forecasting Population, Health Care Costs, and Pension Costs." Demography. 34, no. 1 49-66.

Frankenfield, David C., William Rowe, Stanley Smith, and R. N. Cooney. (2003). "Validation of Several Established Equations for Resting Metabolic Rate in Obese and Nonobese People.” The Journal of the American Dietetic Association 103 9:1152-1159.

Frankenfield, David, Roth-Yousey, Lori, and Compher, Charlene (May 2005). "Comparison of Predictive Equations for Resting Metabolic Rate in Healthy Nonobese and Obese Adults: A Systematic Review". Journal of the American Dietetic Association 105 (5): 775-789. Haines, Michael and Barbara Anderson. "New Demographic History of the Late the Late $19^{\text {th }}$ Century United States." Explorations in Economic History. 25, no. 4 (1988): 341-365. Harris, Arthur and Francis Benedict. 1919. “A Biometric Study of Basal Metabolism in Man.” Carnegie Institution of Washington. Washington DC. 
Hendricks W, Koenker R (1992) Hierarchical spline for conditional quantiles and the demand for electricity. Journal of the American Statistical Association 87: 58-68

Hilliard, Samuel B. Hog, Meat and Hoecake: Food Supply in the Old South, 18401860. Carbondale, IL: Southern Illinois University Press. 1972.

Hirshchi, Travis and Michaeal Gottfredson. (1983). “Age and Explanation of Crime.” American Journal of Sociology 89(3), pp. 552-584.

Kim, John M. “Nutrition and the Decline of Mortality.” In Kenneth Kiple and Kriemheld Ornelas (Eds.). The Cambridge Word History of Food. Cambridge: Cambridge University Press. pp. 1381-1389.

Koenker R, Bassett G (1982) “Tests of linear hypotheses and l $\mathrm{l}_{1}$ estimators.” Econometrica 50: $1577-1584$

Komlos, J., 1987. “The Height and Weight of West Point Cadets: Dietary Change in Antebellum America.” Journal of Economic History 47, 897-927.

Komlos, J., 1992. “Toward an Anthropometric History of African-Americans: The Case of the Free Blacks in Antebellum Maryland.” In: Goldin C., Rockoff, H., (Eds.) Strategic Factors in Nineteenth Century American Economic History: A Volume to Honor Robert W. Fogel. University of Chicago Press, Chicago.

Komlos, J., Coclanis, P., 1997. “On the Puzzling Cycle in the Biological Standard of Living: The Case of Antebellum Georgia.” Explorations in Economic History 34, 433-59.

Komlos, John and Jörg Baten (2004) “Anthropometric Research and the Development of Social Science History.” Social Science History. 28: 191-210.

Koshimizu, Takako, Yoshiko Matsushima , Yukari Yokota, Kae Yanagisawa, Satsuki Nagai, 
Koji Okamura, Yutaka Komatsu, and Takashi Kawahara. (2012). "Basal Metabolic Rate and Body Composition of Elite Japanese Male Athletes.” Journal of Medical Investigation, 59, 253-260.

Ladurie, Le Roy E., 1979. “The Conscripts of 1968: A Study of the Correlation between Geographical Mobility, Delinquency and Physical Stature and Other Aspects of the Situation of the Young Frenchman Called to Do Military Service that Year.” In: Reynolds, B., Reynolds, S., (Eds.). The Territory of the Historian. University of Chicago Press, Chicago.

Livi-Bacci, Massimo. , (1983). "The Nutritional-Mortality Link in Past Times: A Comment." Journal of Interdisciplinary History. 14: 293-298.

Margo, R. Steckel, R, 1982. Heights of American Slaves: New Evidence on Nutrition and Health. Social Science History 6, 516-538.

Margo, R., Steckel, R., 1992. "The Nutrition and Health of Slaves and antebellum Southern whites.” In: Fogel, R.W., Engerman, S., (Ed.), Without Consent or Contract: Conditions of Slave Life and the Transition to Freedom, W.W. Norton, New York, 508-521.

McKeown, Thomas (1976). The Modern Rise of Population. New York: Academic Press. McKeown, Thomas. (1983) "Food, Infection and Population." Journal of Interdisciplinary History. 227-247.

McKeown, Thomas and R. G. Record. (1962). "Reasons for the Decline of Mortality in England and Wales during the Nineteenth Century." Population Studies, 16, 2, 94-122.

Mifflin, M.D., St Jeor, ST, Hill, LA, Scott, BJ, Daugherty, SA and YO Koh (1990). “A new predictive equation for resting energy expenditure in healthy individuals.” American Journal of Clinical Nutrition, Vol 51, pp. 241-247. 
Mitka, Mike. (2013). “Do Flawed Data on Caloric Intake from NHANES Present Problems for Researchers and Policy Makers?” Journal of the American Medical Association 310(20). pp. 2137-2138.

Must, Aviva and Whitney Evans. 2011. “The Epidemiology of Obesity” In: Cawley, John (ed.) The Oxford Handbook of the Social Science of Obesity. 9-34.

Neel, James (1962) “Diabetes Mellitus: A “Thrifty” Genotype Rendered Detrimental by “Progress”? American Journal of Human Genetics 14, 453-362.

Nicholas, S., Steckel, R., 1991. "Heights and Living Standards of English Workers During the Early Years of Industrialization.” Journal of Economic History 51, 937-957.

Oeppen, Jim and James Vaupel, 2002. “Broken Limits to Life Expectancy.” Science 286. pp. 1029-1031.

Ogden, Cynthia, Margaret Carroll, Brian Kit, and Katherine Flegal.(2014). “Prevalence of Childhood and Adult Obesity in the United States, 2011-2012.” Journal of the American Medical Association. 311(8), pp. 806-814.

Olmstead, Alan and Daniel A. Sumner. (2006). "Farm Policy,” in Susan B. Carter, et al., Historical Statistics of the United States: Earliest Times to the Present, Millennial Edition, Cambridge University Press, volume 4, pp. 31-38.

Poehlman, Eric, Christopher Melby, Stephen Badylak and Jorge Calles. (1989). “Aerobic Fitness and Resting Energy Expenditures in Young Adult Males.” Metabolism, 38, pp. 85-90.

Poehlman, Eric, Christopher Melby, and Stephen Badylak. (1988). “Resting Metabolic Rate and Post Prandial Thermogenesis in Highly Trained and Untrained Males.” American Journal of Clinical Nutrition, 47, pp. 793-798. 
Pope, Clayne. (1992). “Adult Mortality in America before 1900.” In Claudia Goldin and Hugh Rockoff (Eds.). Strategic Factors in Nineteenth Century American Economic History: A Volume to Honor Robert Fogel. Chicago: University of Chicago Press. pp. 267-298.

Popkin, Barry. (1993). “Nutritional Patterns and Trends.” Population Development Review, 19, pp. 138-157.

Poston. Walker S. Carlos and John Foreyt. 1999. "Obesity in an Environmental Issue.” Atherosclerosis 146: 201-209.

Prentice, A. M., 2005, "Starvation in Humans: Evolutionary Background and Contemporary Implications.” Mechanisms of Aging and Development 126(9), pp. 976-981.

Prentice, A. M., B.J. Hennig, and A.J. Fulford. 2008. "Evolutionary Origins of the Obesity Epidemic: Natural Selection of Thrifty Genes or Genetic Drift Fallowing Predation Release?” International Journal of Obesity 32(11), pp. 1607-1610.

Preston, Samuel. (1975). “The Changing Relation between Mortality and Level of Economic Development.” Population Studies 29(2), pp. 231-248.

Putnam, Judy 2000. “Major Trends in U.S. Food Supply, 1909-1999.” Food Review. 23(1), pp. 8-15).

Rosen, Stacey 1999. “Most-But Not All-Regions See Food Gains,” Food Consumption and Spending, pp. 13-19.

Rosenbloom, Joshua. (2002). Looking for Work: Searching for Workers. Cambridge: Cambridge University Press.

Shapouri, Shahla and Stacy Rosen 2007. “Global Diet Composition: Factors Behind the Changes and Implications and the New Trends,” Food Security and Assessment 2007, pp. 28-37. Shergold, Peter R. 1982. Working Class Life: The American Standard in Comparative 
Perspective, 1899-1913. Pittsburgh: University of Pittsburgh Press.

Sokoloff, K. \& Villaflor, G. (1982) “Early Achievement of Modern Stature in America,” Social Science History 6, 453-481.

Speakman, J.R. (2008). “Thrifty Genes for Obesity, an Attractive but Flawed Idea, and an Alternative Perspective: the 'Thrifty Gene’ Hypothesis.” International Journal of Obesity. 32 (11), pp. 1611-1617.

Speakman, John R. and Colin Selman (2003). "Physical activity and resting metabolic rate.” Proceedings of the Nutritional Society, 62, pp. 621-630.

Steckel, R., 1979. Slave Height Profiles from Coastwise Manifests. Explorations in Economic History 16, 363-380.

Steckel, R.H. (1983) 'Height and per capita income', Historical Methods, 16: 1-7.

Strauss, John and Duncan Thomas (1998), "Health, Nutrition, and Economic Development.” Journal of Economic Literature, 36: 766-817.

Stevens, June, Jianwen Cai, Kelly Evenson, and Ratna Thomas. 2002. "Fitness and Fatness as Predictors of Mortality from All Causes and from Cariovascular Disease in Men and Women in the Lipid Research Clinics Study.” American Journal of Epidemiology. 156: 2002.

Tanner, J.M., 1977. Human Growth and Constitution. In: Harrison, G.A., Weiner, J.S., Tanner, J.M., Barnicot, N.A. (Eds.), Human Biology: an Introduction to Human Evolution, Variation, Growth and Ecology. Oxford University Press, Oxford.

Thomasson, Melissa (2013). “Economic History and Healthcare,” in Robert Whaples and Randall Parker (Eds.). Routledge Handbook of Modern Economic History. Routledge Press: New York, pp. 177-188. 
US Bureau of the Census, 1975. Bicentennial Edition: Historical Statistics of the United States, Colonial Times to 1970. Washington, DC. US Government Publishing Office.

Wardlaw, Gordon, Jeffrey Hampl, and Robert Disilvestro. 2004. Perspectives in Nutrition, $6^{\text {th }}$ Edition. New York: McGraw Hill.

Weijs, Peter, Hinke M. Kruisenga, Aimee van Dijk, Barbara van der Meij, Jacqueline Langius, Dirk Knol, Robert Strack van Schijndel, Marian van Bokhorst-de van der Schueren. 2008. "Validation of Predictive Equations for Resting Energy Expenditure in Adult Outpatients and Inpatients.” Clinical Nutrition 27, pp. 150-157. 